\title{
Antioxidant, Antiglycation and in vivo Antiaging Effects of Metabolite Extracts from Marine Sponge-associated Bacteria
}

\author{
M. E. PRASTYA, R. I. ASTUTI, I. BATUBARA ${ }^{1,2}$ AND A. T. WAHYUDI*
}

Department of Biology, ${ }^{1}$ Department of Chemistry, Faculty of Mathematics and Natural Science, Bogor Agricultural University, Bogor 16680, ${ }^{2}$ Tropical Biopharmaca Research Center, Bogor Agricultural University, Bogor 16128, Indonesia

Prastya et al.: Antiaging Effect of Metabolite Extracts from Marine Sponge-associated Bacteria

\begin{abstract}
In vitro antioxidant, antiglycation activities of marine sponge-associated bacterial extracts and potential antiaging properties on the model organism, fission yeast (Schizosaccharomyces pombe) were investigated in the present study. Spectrometry method was used to assess the chemical contents of the extracts. Antioxidant activity was measured using 2,2-diphenyl-1-picrylhydrazyl and 2,2'-azino-bis(3-ethylbenzothiazoline6-sulphonic acid) radicals, while antiglycation was a fluorometric assay. Antiaging activity was tested using the spot test and chronological life span assays. In addition, mitochondrial activity, intracellular reactive oxygen species level and cell cycle analysis of Schizosaccharomyces pombe were evaluated to understand fully the effect of the selected extract. Highest amount of phenolic compounds was found in HAL-13 extract of $215.15 \mathrm{mg}$ gallic acid equivalents/g extract. PTR-21 extract has the highest flavonoid and tannin contents of $6.42 \mathrm{mg}$ quercetin equivalents/g extract and $5.88 \mathrm{mg}$ catechin/g extract, respectively. The best antioxidant activity was found in HAL-08 extract with $\mathrm{IC}_{50}$ value of 17.10 and $59.39 \mu \mathrm{g} / \mathrm{ml}$ in the two antioxidant assays employed, while the highest activity of antiglycation was reported in the PTR-21 extract with $\mathrm{IC}_{50}$ value of $157.50 \mu \mathrm{g} / \mathrm{ml}$. PTR-21 $(500 \mu \mathrm{g} / \mathrm{ml})$ extract exhibited antiaging properties in Schizosaccharomyces pombe. Indeed, PTR-21 extract could extend G1 phase of the cell division from 26 to $40 \%$. Interestingly, the corresponding extract could enhance the stress tolerance of phenotype in Schizosaccharomyces pombe against $\mathrm{H}_{2} \mathrm{O}_{2}$-induced oxidative stress. Such phenotypes might be induced by mitochondrial-reactive oxygen species adaptive signalling, as the extract application significantly enhanced yeast mitochondrial respiratory activity.
\end{abstract}

Key words: Sponge-associated bacteria, antioxidant, antiglycation, antiaging, Schizosaccharomyces pombe

Marine sponges are evolutionary multicellular organisms that have been reported as the best producers of bioactive compounds, which have antibacterial, antifungal, anticancer and cytotoxic properties ${ }^{[1]}$. The limitations of sponge biomass and ecological problems such as marine environmental damage and sponge extinction are the main factor for isolating the large scale bioactive compounds. Interestingly, a previous research showed that 40-60\% of sponge biomass is symbiotic microorganisms that can produce metabolite compounds similar to those produced by the host. It is hypothesized that symbiotic marine-microorganisms harbored by sponges are the original producers of these bioactive compounds ${ }^{[2]}$. Previous studies had revealed the antioxidant and anticancer activity of bacterial crude extracts isolated from sponge Jaspis sp. against human cervix HeLa cells and leukemic cell lines ${ }^{[3,4]}$. In addition, crude extract of Bacillus sp. isolated from sponge Haliclona sp. was also reported to have anticancer activity against MOLT4 cells and its activity is related to NRPS-PKS genes to encode the bioactive compounds $^{[5]}$.

Antioxidant activity plays an important role in cellular physiology as it has the ability to neutralize and prevent free radicals, including reactive oxygen species (ROS) and its derivatives, from damaging cells. However, an imbalance between ROS production and antioxidant defence may lead to oxidative stress, which may cause degenerative diseases such as cancer, Alzheimer's, cardiovascular, aging and neurological disorders ${ }^{[6]}$.

This is an open access article distributed under the terms of the Creative Commons Attribution-NonCommercial-ShareAlike 3.0 License, which allows others to remix, tweak, and build upon the work non-commercially, as long as the author is credited and the new creations are licensed under the identical terms

Accepted 25 February 2019

Revised 10 October 2018

Received 17 July 2018

Indian J Pharm Sci 2019;81(2):344-353 
Many studies have reported antioxidant compounds that prevent the premature aging of skin cells in the form of cosmetics or prevent the occurrence of degenerative diseases originating from plant extracts. Tillah et al. ${ }^{[7]}$ reported the antioxidant activity of resins and essential oil from some pines promising as antiaging compounds. Stem bark extract from Anacardium occidentale was also reported to having antioxidant activity ${ }^{[8]}$.

The phenomenon of glycation has also been intensively studied, since it is highly related to the development of some degenerative diseases such as diabetes, cancer or Alzheimer's. Glycation is a non-enzymatic formation from amino groups of protein and the carbonyl groups of reduced sugars to form advanced glycation end products (AGEs). The accumulation of protein glycation products in living organisms leads to structural and functional modifications of tissue and proteins ${ }^{[9]}$. The accumulation of ROS and AGEs molecules may significantly accelerate cellular aging than normal cells. Thus, antioxidant and antiAGEs are needed to neutralize ROS and AGEs inside cells.

Aging is a complex process involving physiological and molecular mechanisms inside cells. Fission yeast Schizosaccharomyces pombe is one of the popular eukaryotic model organisms widely used for studying cellular biology and molecular events including cell cycle regulation, DNA repair and signal transduction ${ }^{[10]}$. This is because some of the molecular signals or pathways are similar to the mammalian cells. The conserve mRNA splicing process with metazoan indicated mitochondrial inheritance mechanisms similar to mammalian cells ${ }^{[11]}$. Some compounds have been investigated to uncover the antiaging mechanism in $S$. pombe. Monensin and prostaglandin $\mathrm{J} 2$ were reported to affect vacuolar acidification and the role for mitochondrial fission in $S$. pombe, respectively ${ }^{[12]}$.

Currently, many supplements, cosmetics or antiaging drugs have been developed. However, antioxidant, antiglycation and in vivo antiaging activities from marine sponge-associated bacterial extracts have not been studied. In the present study, the potential pharmaceutical properties of marine spongeassociated bacterial extracts including antioxidant and antiglycation activities in vitro were reported as well as their potential antiaging properties by using $S$. pombe as a model organism was investigated.

\section{MATERIALS AND METHODS}

Bacteria used in this study were collected from previous research. HAL-08, HAL-13 and HAL-74 were isolated from sponge Haliclona sp. taken from Waigeo Island Raja Ampat Papua, Indonesia ${ }^{[13]}$. PTR-21 was isolated from sponge Petrosia sp. taken from Bira Island, Jakarta, Indonesia ${ }^{[14]}$. Extraction was carried out using a previously reported method ${ }^{[3]}$ with some modifications. About $1 \%$ of liquid bacteria from the main culture was re-inoculated on sea water complete liquid medium and incubated at $25-27^{\circ}, 120 \mathrm{rpm}$ for $3 \mathrm{~d}$. Bacterial cultures were mixed with ethyl acetate $(1: 1)$ and shaken at room temperature for $20 \mathrm{~min}$. The ethyl acetate layer was separated and evaporated. Chemical constituents were analysed using spectrometric methods for determining the total phenolic, flavonoid and tannin contents as described previously ${ }^{[15]}$.

\section{2,2-diphenyl-1-picryl-hydrazil (DPPH) scavenging assay:}

The DPPH assay was performed as described by Batubara et al. ${ }^{[16]}$. Briefly $100 \mu 1$ of DPPH solution (125 $\mu \mathrm{M}$ in ethanol) was mixed with $100 \mu 1$ of different concentrations of bacterial extract and standard (ascorbic acid and Trolox). The mix was incubated for $30 \mathrm{~min}$ and the optical density was measured at $515 \mathrm{~nm}$ using an ELISA microtiter plate reader (EPOC, USA). Percent inhibition was calculated using the formula, $(\%)$ inhibition $=[1-(\mathrm{A}-\mathrm{C}) /(\mathrm{B}-\mathrm{C}) \times 100]$, whereas $\mathrm{A}$ is absorbance of DPPH in the presence of extract/standard, B is absorbance of DPPH blank with ethanol and $\mathrm{C}$ is absorbance of ethanol. The results are expressed as inhibitory concentration of $50 \%\left(\mathrm{IC}_{50}\right)$.

\section{2,2'-azino-bis(3-ethylbenzothiazoline-6-sulphonic acid) or ABTS radical scavenging activity:}

The antioxidant capacity using ABTS radical cation was determined according to Zahra et al. ${ }^{[17]}$. ABTS solution $(7 \mathrm{mM})$ was oxidized by potassium peroxide sulphate for 12-16 h. Furthermore, about $180 \mu \mathrm{l}$ ABTS radical was reacted with $20 \mu \mathrm{l}$ sample and incubated for $30 \mathrm{~min}$. The absorbance was measured at $734 \mathrm{~nm}$ and the percent inhibition was calculated using the formula, $(\%)$ inhibition $=[1-(\mathrm{A}-\mathrm{C}) /(\mathrm{B}-\mathrm{C})] \times 100$, whereas $\mathrm{A}$ is absorbance of ABTS in the presence of extract/standard (ascorbic acid and Trolox), B is absorbance of ABTS blank with ethanol and $\mathrm{C}$ is absorbance of ethanol. The results are expressed as inhibitory concentration of $50 \%\left(\mathrm{IC}_{50}\right)$.

\section{Antiglycation activity:}

Antiglycation activity was conducted based on of Zahra et al. ${ }^{[17]}$. The reaction consisted of BSA 
(20 $\mathrm{mg} / \mathrm{ml})$, glucose $(235 \mathrm{mM})$, fructose $(235 \mathrm{mM})$ and $50 \mu \mathrm{l}$ of sample or positive control (aminoguanidine hydrochloride, Sigma) in phosphate buffer $0.2 \mathrm{M}$ (pH 7.4). Briefly, sample corrected solution was prepared similar to the sample, in which water was used to replace glucose and fructose. All solutions were incubated for $40 \mathrm{~h}$ at $60^{\circ}$ and then the excitation fluorescence intensity was measured at $330 \mathrm{~nm}$ and the emission at $440 \mathrm{~nm}$ by using fluorometer (FLUOstar Omega microplate reader, BMG Labtech, Germany). Extent of inhibition was calculated using the Eqn., inhibition $(\%)=[1-(\mathrm{A}-\mathrm{A} 1) /(\mathrm{B}-\mathrm{B} 1)] \times 100$, where A was the fluorescence intensity of sample solution; A1 was the fluorescence intensity of sample correction solution; B was the fluorescence intensity of control solution; B1 was the fluorescence intensity of control correction solution. Concentration that produced 50 $\%$ inhibition $\left(\mathrm{IC}_{50}\right)$ of AGE molecule was calculated using a linear regression approach.

\section{Antiaging activity based on spot assay:}

Spot assay was conducted with a slight modifications of a procedure that was described earlier ${ }^{[18]}$. Wild type of S. pombe ARC039 (h-leu1-32 ura4-294) was cultured on yeast extract supplement (YES) liquid medium containing $3 \%$ glucose, shaken at $300 \mathrm{rpm}$ and incubated for $24 \mathrm{~h}$ at $30^{\circ}$ as inoculum. The inoculum was re-inoculated on $3 \mathrm{ml}$ YES test culture (on a $20 \mathrm{ml}$ test tube) with an initial $\mathrm{OD}_{600}$ of 0.05 as treatment culture. Each bacterial extract (500 $\mu \mathrm{g} / \mathrm{ml}$ diluted with DMSO) was supplemented in the treatment culture. S. pombe on YES and Edinburg minimum medium (EMM) containing $0.5 \%$ glucose without extracts and supplemented with DMSO was designed as negative and positive control, respectively. Each culture was incubated for $11 \mathrm{~d}$ at $30^{\circ}$ by shaking at $300 \mathrm{rpm}$ (Bio Shaker BR-23FP, Japan). Spot assay was conducted on day 1,7 and 11 from the same culture starting with set $\mathrm{OD}_{600}$ of 1 from all cultures. Subsequently, serial diluting was conducted from $\mathrm{OD}_{600} 1$ to $10^{-4}$ on sterile 96 -well plate. About $3 \mu \mathrm{l}$ of each dilution was spotted on YES solid medium and incubated for $3 \mathrm{~d}$ at $30^{\circ}$. The density of the grown cells from each spot was considered as the viability of $S$. pombe cells. In observing the optimum concentration of antiaging activity from selected extract, spot assay was performed as described above. However, the amount of concentration from selected extract varied, including 100, 250, 500, 750 and $1000 \mu \mathrm{g} / \mathrm{ml}$.

\section{Oxidative stress tolerance assay:}

Spot assay was performed as described above, in which various concentration of $\mathrm{H}_{2} \mathrm{O}_{2}$-supplemented on YES solid medium for spot test was used as oxidative stress medium.

\section{Antiaging activity based on chronological life span (CLS) assay:}

CLS assay was performed based on Roux et al. ${ }^{[18]}$ with some modifications. Fresh $S$. pombe was inoculated into $10 \mathrm{ml}$ of YES liquid medium and grown for $24 \mathrm{~h}$ as inoculum. As a treatment culture, inoculum was inoculated into $50 \mathrm{ml}$ (on $250 \mathrm{ml}$ flask) of YES liquid medium with an initial $\mathrm{OD}_{600}$ of 0.05 then added with selected extract at the best concentration. $S$. pombe on EMM liquid medium and YES liquid medium supplemented with DMSO were set as positive and negative controls, respectively. Cultures were grown by shaking $(120 \mathrm{rpm})$ at $30^{\circ}$ until day 20 . Maximum cell density was reached approximately after $24 \mathrm{~h}$ of growth in YES liquid medium. Therefore, 1 day after inoculation was considered as day 1 of CLS. Subsequently, cellular viability was determined at day $1,4,7,10,14,17$ and 20 by using total plate count method. Serial dilution was determined by setting the optical density $\left(\mathrm{OD}_{600}=1\right)$ for selected day culture. Furthermore, each dilution was plated to YES solid medium of $100 \mu \mathrm{l}$ per plate with three replicates. Plates were incubated at $30^{\circ}$ for $3 \mathrm{~d}$ and yeast colonies were counted.

\section{Observation of active mitochondria:}

Mitochondrial activity was observed with a fluorescent dye rhodamine 123 (Sigma Aldrich), used to monitor yeast mitochondrial membrane potential. Various concentrations of selected extracts were added to $S$. pombe culture in $3 \mathrm{ml}$ YES medium with an initial $\mathrm{OD}_{600}$ of 0.05 . Treatment was conducted until $\mathrm{OD}_{600}$ of 1 . Cells were then harvested by centrifugation prior to suspending it in $50 \mathrm{mM}$ sodium citrate buffer ( $\mathrm{pH} 5.0)$ containing $2 \%$ glucose. Subsequently, rhodamine 123 was added at a final concentration of $50 \mathrm{mM}$ to the cell suspensions, and the stained yeast cells were observed with a fluorescent microscope Axiovert 200M (Carl Zeiss, Germany).

\section{Intracellular ROS measurement using flow cytometry:}

Intracellular ROS measurement was monitored by flow cytometry based on previous research ${ }^{[19]}$ with 
some modifications. After growing $S$. pombe on designated treatment conditions as mentioned above at the optimum concentration of selected extracts, yeast cells were harvested, washed, and suspended in $1 \mathrm{ml}$ of $50 \mathrm{mM}$ potassium phosphate buffer (pH 7.4) containing $10 \mathrm{mM}$ of 2',7'-dichlorofluorescein diacetate (DCFDA, Ana Spec Inc). DCFDA treatment was conducted for $30 \mathrm{~min}$ prior to the flow cytometry analysis and light exposure was avoided as far as possible during the experiment. Positive control was conducted using $1 \mathrm{mM} \mathrm{H}_{2} \mathrm{O}_{2}$ treatment to the culture $2 \mathrm{~h}$ prior to being harvested. The fluorescence intensity was quantified by using the BD Accuri C6 instrument (BD Biosciences, USA) with the FL1-H channel using $488 \mathrm{~nm}$ for excitation and $530 \mathrm{~nm}$ for emission.

\section{Cell cycle analysis:}

Cell cycle analysis was performed based on the method of Boye et al. ${ }^{[20]}$ with some modifications. Selected extract at the best concentration was added to $S$. pombe culture in $3 \mathrm{ml}$ YES medium with initial $\mathrm{OD}_{600}$ of 0.05 . It was then incubated for $18 \mathrm{~h}$. Cells were then harvested by centrifugation prior to washing with phosphate buffer saline (PBS). Subsequently, cells were fixed in $70 \%$ cold ethanol and stored at $4^{\circ}$ for $6-24 \mathrm{~h}$. The cells were washed in PBS buffer and treated with $50 \mu 1$ of $100 \mu \mathrm{g} / \mathrm{ml} \mathrm{RNase}$ for $30 \mathrm{~min}$ at $37^{\circ}$. RNase were removed, washed and the cells were diluted with $300 \mu 1$ of $50 \mu \mathrm{g} / \mathrm{ml}$ propidium iodide (ThermoFischer Scientific) then incubated for $60 \mathrm{~min}$ at room temperature covered by foil. The fluorescence signal was analysed by using the BD Accuri C6 instrument (BD Biosciences, USA) with the FL2-A channel using $535 \mathrm{~nm}$ for excitation and $617 \mathrm{~nm}$ for emission. FlowJO, LLC V10 software was used to determine each phase of cell cycle.

Identification of bacteria using morphological and biochemical tests and phytochemical analysis:

Selected bacterial isolate was identified using morphological and biochemical analysis based on key identification of Bergey's Manual of Determinative
Bacteriology ${ }^{[21]}$. Selected extract was screened for alkaloids, flavonoids, saponins, tannins, terpenoid and steroids as described by Gochukwu et al. ${ }^{[22]}$.

\section{Statistical analysis:}

Statistical analysis was performed as means \pm SD from three independent replicates. One-way analysis of variance was employed for comparing of the mean values with $95 \%$ confidence level. Further analysis was performed by multiple Duncan test range test. Linear regression analysis to determine $\mathrm{IC}_{50}$ was performed using Microsoft Excel 2016. In each analysis $p<0.05$ was considered statistically significant.

\section{RESULTS AND DISCUSSION}

In the present study, total phenolic content was estimated using the Folin-Ciocalteu reagent method and expressed as milligram gallic acid equivalent (GAE)/g of dry extract. The results showed that all samples had phenolic content from 90.03 to $215.15 \mathrm{mg}$ GAE/g. The highest amount of phenolic compounds was recorded in HAL-13 extract, followed by HAL-08, PTR-21 and HAL-74. In addition, all bacterial extracts had flavonoid contents ranging from 2.20 to $6.42 \mathrm{mg}$ quercetin equivalents/g, in which PTR-21 extract had the highest flavonoid content. Interestingly, PTR-21 extract also had the highest tannin amount of $5.88 \mathrm{mg}$ catechin equivalents $/ \mathrm{g}$ compared to other samples (Table 1).

The results showed that bacterial extract from HAL13 had the highest amount of total phenolic. On the other hand, PTR-21 extract had the highest amount of flavonoid and tannin content. However, there is little information regarding chemical contents of sponge-associated bacterial extracts. Indeed, previous reports indicated the chemical contents of plant extracts and their correlation with antioxidant activity. Methanol extract of leaves from Garcinia lancifolia was reported to have a total phenolic content of $828 \mathrm{mg} \mathrm{GAE} / \mathrm{g}$, which correlated well with high antioxidant activity ${ }^{[23]}$. In accordance with this reported observation, the contribution of phenolic compounds

TABLE 1: TOTAL PHENOLIC, FLAVONOID AND TANNIN CONTENT OF BACTERIAL EXTRACTS

\begin{tabular}{lccc}
\hline Bacterial extracts & Total phenolic (mg GAE/g) & $\begin{array}{c}\text { Total flavonoid (mg quercetin } \\
\text { equivalents/g) }\end{array}$ & $\begin{array}{c}\text { Total tannin (mg catechin } \\
\text { equivalents/g) }\end{array}$ \\
\hline PTR-21 & $152.06 \pm 10.20^{\mathrm{b}}$ & $6.42 \pm 0.43^{\mathrm{c}}$ & $5.88 \pm 0.48^{\mathrm{b}}$ \\
HAL-08 & $179.80 \pm 4.58^{\mathrm{c}}$ & $4.99 \pm 0.38^{\mathrm{b}}$ & $2.60 \pm 0.38^{\mathrm{a}}$ \\
HAL-13 & $215.15 \pm 2.98^{\mathrm{d}}$ & $2.20 \pm 0.24^{\mathrm{a}}$ & $2.55 \pm 0.98^{\mathrm{a}}$ \\
HAL-74 & $90.03 \pm 1.29^{\mathrm{a}}$ & $4.26 \pm 0.30^{\mathrm{b}}$ & $1.85 \pm 0.14^{\mathrm{a}}$ \\
\hline
\end{tabular}

Values with the same superscript letter are not significantly difference $(p<0.05)$ 
TABLE 2: ANTIOXIDANT AND ANTIGLYCATION ACTIVITY OF ETHYL ACETATE-DERIVED BACTERIAL EXTRACTS

\begin{tabular}{lccc}
\hline Samples & DPPH IC $_{50}(\mu \mathrm{g} / \mathrm{ml})$ & ABTS IC $_{50}(\mu \mathrm{g} / \mathrm{ml})$ & Antiglycation IC $_{50}(\mu \mathrm{g} / \mathrm{ml})$ \\
\hline Aminoguanidine & $\mathrm{NA}$ & $\mathrm{NA}$ & $20.54 \pm 0.58^{\mathrm{a}}$ \\
Trolox & $1.99 \pm 0.03^{\mathrm{a}}$ & $11.36 \pm 0.11^{\mathrm{a}}$ & $\mathrm{NA}$ \\
Ascorbic acid & $4.42 \pm 0.02^{\mathrm{a}}$ & $21.04 \pm 0.17^{\mathrm{a}}$ & $\mathrm{NA}$ \\
PTR-21 & $36.14 \pm 2.23^{\mathrm{c}}$ & $254.51 \pm 13.37^{\mathrm{d}}$ & $157.50 \pm 1.08^{\mathrm{b}}$ \\
HAL-08 & $17.10 \pm 0.67^{\mathrm{b}}$ & $59.39 \pm 1.17^{\mathrm{b}}$ & $206.40 \pm 2.98^{\mathrm{d}}$ \\
HAL-13 & $33.69 \pm 2.31^{\mathrm{c}}$ & $140.34 \pm 2.20^{\mathrm{c}}$ & $209.30 \pm 3.60^{\mathrm{d}}$ \\
HAL-74 & $599.51 \pm 6.44^{\mathrm{d}}$ & $463.93 \pm 59.74^{\mathrm{e}}$ & $184.40 \pm 4.60^{\mathrm{c}}$ \\
\hline
\end{tabular}

Values with the same superscript letter are not significantly difference $(p<0.05)$; NA-not applicable; $I C_{50}$ indicates the ability of crude extracts to stabilize $50 \%$ reactivity of the designated free radicals

to antioxidant properties and their correlation with in vitro antiglycation activity of the bacterial extracts was evaluated.

Antioxidant activity was evaluated using the DPPH and ABTS methods. Among the isolates tested, highest antioxidant activity was shown by the crude extract of HAL-08 with $\mathrm{IC}_{50}$ value of 17.10 and $59.39 \mu \mathrm{g} / \mathrm{ml}$ for DPPH and ABTS radicals, respectively. On the other hand, the highest antiglycation activity was found in the crude extract of PTR-21 with $\mathrm{IC}_{50}$ value of $157.50 \mu \mathrm{g} / \mathrm{ml}$. However, the $\mathrm{IC}_{50}$ of both antioxidant and antiglycation activities of the bacterial crude extracts tested, was lower than that showed by positive control (Table 2). This appeared to be due to the utilization of crude extract in the assay, which contained various types of bioactive compounds. Previous study reported that DPPH antioxidant activity of ethyl acetate-derived bacterial extract isolated from sponge Callyspongia diffusa exhibited an $\mathrm{IC}_{50}$ of $857.49 \mu \mathrm{g} / \mathrm{ml}^{[24]}$. The present data showed that extracts HAL-08 and PTR-21 had $\mathrm{IC}_{50}$ values 17 to 19-fold higher than that reported in the previous study. At the same time, reports on antiglycation activity of sponge-associated bacterial extracts are still limited. Indeed, some previous studies reported antiglycation activity from plant extracts. Crude extracts from Zingiber zerumbet and essential oil of Zingiber officinale were reported to possess antiglycation activity with $\mathrm{IC}_{50}$ values of 377.95 and $207.95 \mu \mathrm{g} / \mathrm{ml}$, respectively ${ }^{[17,25]}$. In this context, the extract PTR-21 exhibited $\mathrm{IC}_{50}$ value that was 0.25 to 2-fold higher than other extracts.

The effect of bacterial extracts on the viability of $S$. pombe was further examined to understand the potential antiaging activity in vivo. Initial screening was done by testing each bacterial extract at a concentration of $500 \mu \mathrm{g} / \mathrm{ml}$. Amongst the extracts tested, PTR-21 appeared to be the most potential antiaging agent.

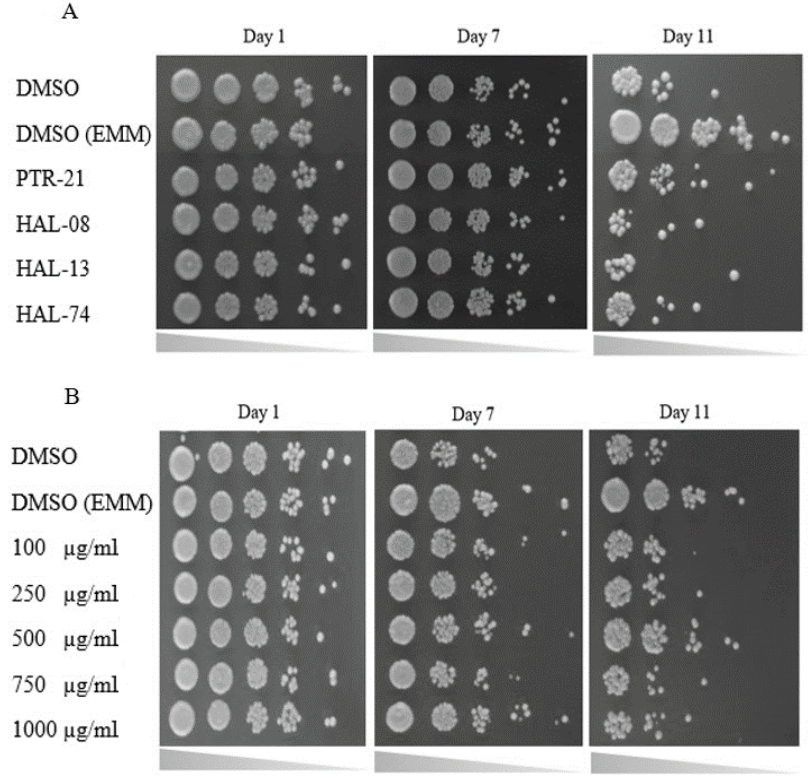

Fig. 1: Screening for lifespan-extending effect of bacterial extracts in $S$. pombe

A. Amongst extract tested, PTR-21 extract is capable to induce longevity of $S$. pombe cells. Each bacterial extract used was dissolved in DMSO and applied at concentration of $500 \mu \mathrm{g} / \mathrm{ml}$. S. pombe grown in YES and EMM with DMSO supplementation was used as negative and positive control, respectively. $B$. PTR-21 extract extends the life span of $S$. pombe cells at a concentration of $500 \mu \mathrm{g} / \mathrm{ml}$

The viability of $S$. pombe was better than that without treatment (negative control) as well as other extracts tested on day 11 of culture based on spot assay (fig. 1A). The optimum concentration of PTR-21 extract to promote yeast cells viability was $500 \mu \mathrm{g} / \mathrm{ml}$ (fig. 1B). Such a result was supported by CLS assay as life span of $S$. pombe was prolonged by PTR-21 extract treatment compared to that without treatment (fig. 2). Indeed, application of PTR-21 promoted the longevity of $S$. pombe until day 20, while it could maintain cells viability only until day 13 without extract treatment. In addition, crude extract of PTR-21 $500 \mu \mathrm{g} / \mathrm{ml}$ was capable of inducing yeast tolerance against $1 \mathrm{mM}$ $\mathrm{H}_{2} \mathrm{O}_{2}$-induce oxidative stress until day 11 (fig. 3). 


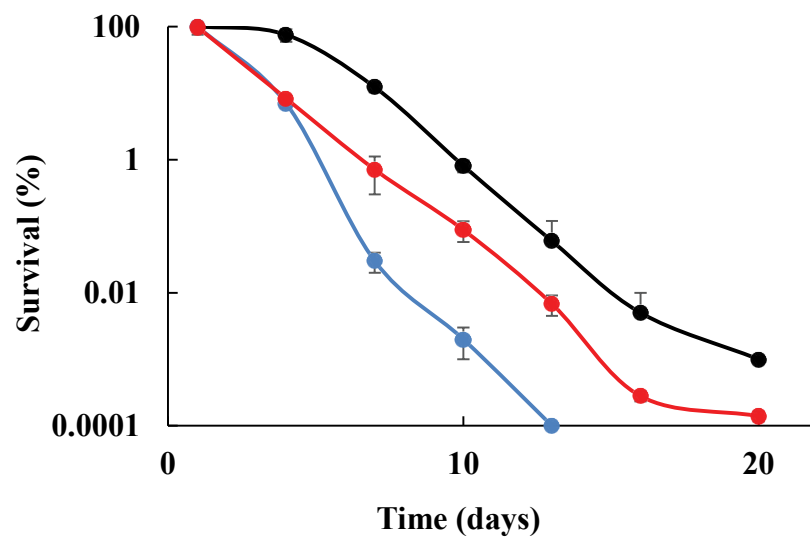

Fig. 2: Lifespan-extending effect of PTR-21 extracts $(500 \mu \mathrm{g} /$ ml) based on CLS assay

—-DMSO (EMM); ——PTR-21; —-DMSO. Yeast cells viability at day 0 (reaching stationary phase, approximately $24 \mathrm{~h}$ after inoculation) was set to $100 \%$ and subsequent survival in the aging culture was normalized to day 0 . Red curve indicates $S$. pombe supplemented with PTR-21 extracts of $500 \mu \mathrm{g} / \mathrm{ml}$, while Blue and black curves indicate $S$. pombe (YES) as negative control and $S$. pombe (EMM) as positive control, respectively. Both of controls supplemented with DMSO

Notably, $S$. pombe is one of the model organisms that was reported to have a unique physiological response upon calorie restriction conditions (CR). CR, defined by reduction in nutrient availability (such as EMM medium) without malnutrition, has been demonstrated to increase yeast life $\operatorname{span}^{[18]}$. In a recent study, we used $S$. pombe cells grown in EMM medium containing $0.5 \%$ glucose as positive control. CR was found to have the ability to increase yeast longevity by inhibiting some glucose signalling pathways including Sck2, Git3/PKA1 and TOR signalling resulting in low intracellular toxic ROS level ${ }^{[11,18]}$. At the same time, CR also increased the expression of Sir2-family of protein deacetylases (sirtuins). High expression of Sir2 protein can maintain genome stability of destructive effect from extra-chromosomal circles of rDNA, thus increasing yeast life $\operatorname{span}^{[26]}$. Intriguingly, CR can induce $S$. pombe metabolism to respiration rather than glucose fermentation during exponential growth. This phenomenon can reduce the accumulation of toxic ethanol and acetic acid level produced during glucose fermentation. At the same time, such a system can increase yeast mitochondrial activity, resulting in mild increased level of intracellular ROS that triggers oxidative stress response (adaptive mechanism) through activation of antioxidant defences mechanism in early growth ${ }^{[27,28]}$.

Based on our experiment, treatment of PTR-21 extract in high glucose medium ( $3 \%$ glucose) as well as other bacterial extracts, resulted in a shorter life span of $S$. pombe compared to that with $0.5 \%$ glucose treatment (fig. 1A). Thus, it is suggested that the corresponding extract was insufficient to render the $S$. pombe systems more resistant with intra and extra-cellular factors affecting aging. Since $S$. pombe growth on high glucose showed activation of nutrient signalling Sck2 and Pka1, reduced Sir2-family or accumulation of toxic ethanol and acetic acid produced during fermentation ${ }^{[26-28]}$. These processes cannot be counteracted with the effect of the corresponding extract. However, treatment of PTR-21 extract could significantly increase the oxidative stress tolerance of phenotype in $S$. pombe cells compared to that with $0.5 \%$ glucose treatment (fig. 3). Such results indicated the potential properties of PTR-21 extract as pro-oxidant, as the extract could induce physiology mechanisms of $S$. pombe to combat oxidative stress, even in non-CR conditions. In order to reveal the mechanism of PTR-21 extract to promote life span in $S$. pombe, we further investigated certain cellular systems that might be altered following extract treatment, including mitochondrial activity, intracellular ROS content and cell cycle distribution.

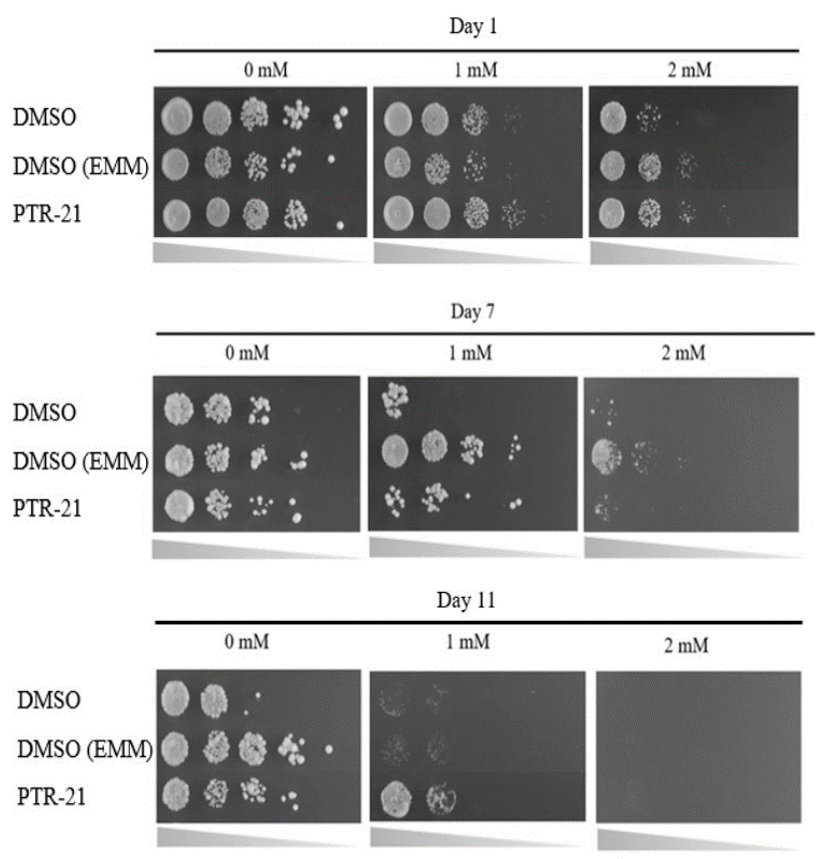

Fig. 3: Effect of PTR-21 extracts $(500 \mu \mathrm{g} / \mathrm{ml})$ on the longevity of $S$. pombe cells against $\mathrm{H}_{2} \mathrm{O}_{2}$-induced oxidative stress

Yeast cells were grown in YES medium containing extract $(500 \mu \mathrm{g} / \mathrm{ml})$ as treatment. Positive control was prepared in EMM (0.5 glucose) medium. Negative control was prepared in YES medium without extract supplementation. Both of positive and negative control were supplemented with DMSO. All cultures were then incubated as indicated in the figure. Spot was conducted on YES solid medium containing various concentration of $\mathrm{H}_{2} \mathrm{O}_{2}$ 
These results showed that PTR-21 extract could induce mitochondrial respiratory system in log phase in a dose-dependent manner (fig. 4). For instance, the intracellular ROS level was increased by treatment with the extract (fig. 5). Mitochondrial organelle was reported to have a basic role in aging and age-related neurodegenerative diseases. This organelle contributed to the ATP production, imbalanced ROS and cell homeostasis, becoming a basic role of the cells ${ }^{[29]}$. Based on these results, high mitochondrial activity in log phase may lead to the higher ROS production. It was hypothesized that PTR-21 extract would likely increase the cellular ROS level during log phase leading to the modulation of stress responsive genes, especially of that oxidative stress responsive genes. As a result, cellular ROS level is likely to be reduced in the stationary phase that would eventually promote cells longevity. Consistent with this, previous results indicated that PTR-21 extract treatment could induce oxidative stress tolerance phenotype in $S$. pombe (fig. 3). Such stress tolerance phenotype was found to be higher in the stationary phase, compared to that without extract and CR treatment.

The data obtained indicated that the beneficial effect of PTR-21 extracts on $S$. pombe cells could result from prooxidant mechanism. In general, pro-oxidant mechanism is closely related to hormesis theory which states, that mild dose of stress-inducing factors could lead to stimulatory response and improvement of biological function, whereas at high doses the deleterious effect would prevail. Since this phenomenon was observed in various organisms, from bacteria to human, these mechanisms might activate defence pathways ensuring protection against higher doses of the same agent (preadaptation) as well as another specific stressor ${ }^{[30]}$. In this case, one possibility is that PTR-21 extract increased the cellular ROS level during log phase on mild condition, triggering oxidative stress adaptation, thus activating several defence mechanisms to cope with the perilous effects of ROS on stationary phase leading to cells longevity. Previous findings reported the beneficial effect of pro-oxidant mechanism on some compounds

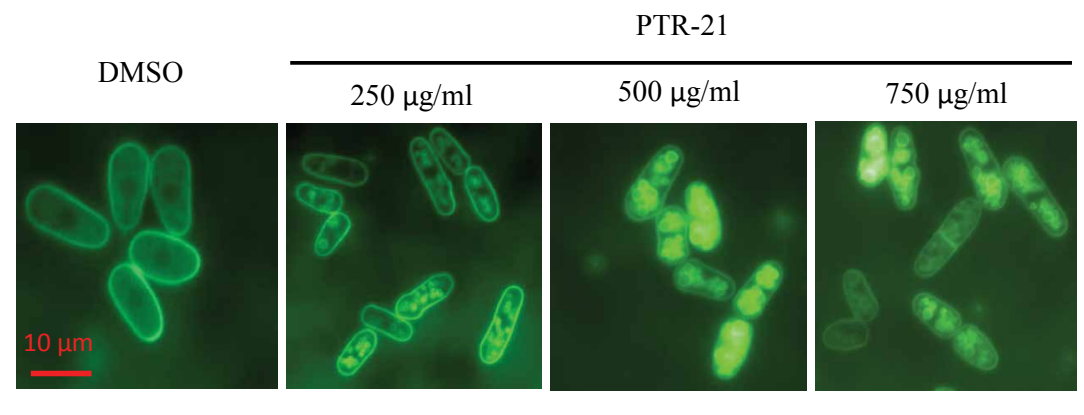

Log phase

Fig. 4: Effect of PTR-21 extracts on the mitochondrial respiratory activity of $S$. pombe based on rhodamine 123 staining Bright green fluorescent signals indicate active mitochondria respiratory systems. All figures are representative from three independent experiments
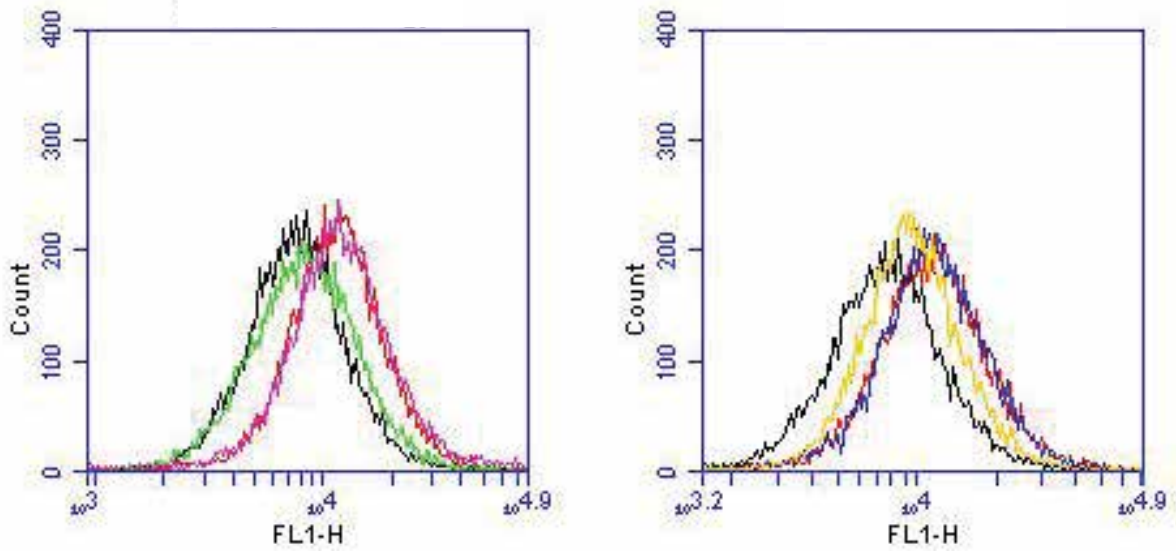

Fig. 5: The effect of PTR-21 extract $(500 \mu \mathrm{g} / \mathrm{ml})$ on the yeast intracellular ROS level

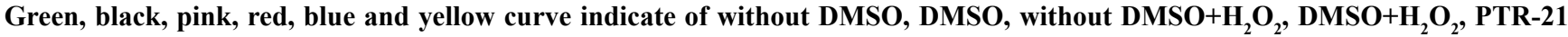
and PTR-21 $+\mathrm{H}_{2} \mathrm{O}_{2}$, respectively. $1 \mathrm{mM} \mathrm{H} \mathrm{H}_{2}$ was applied $2 \mathrm{~h}$ before cell harvested as oxidative stress treatment. All figures are means and representative from three independent experiments 
to increase $S$. pombe life span. Compounds such as 3,3-diindolylmethane from Brassica $\mathrm{sp}$. vegetable and Phloxin B were reported to increase intracellular ROS level during $\log$ phase $^{[12,31]}$. Therefore, antioxidative systems have been induced.

TABLE 3: IDENTIFICATION OF PTR-21 BACTERIA BASED ON BIOCHEMICAL TESTS

\begin{tabular}{lc}
\hline Biochemical tests & Results \\
\hline Oxidase test & + \\
Catalase activity & + \\
Oxidation-fermentation test & + \\
Carbohydrate fermentation & - \\
Glucose & - \\
Lactose & - \\
Maltose & - \\
Arabinose & - \\
Galactose & Yellow fluorescent of \\
Growth on pseudo F agar & bacterial colony \\
\hline++ ' Indicates positive reaction, ‘-’ indicates negative reaction
\end{tabular}

In this study, these finding could be extended by analysing the effect of potential extract on the yeast cell cycle profile. Interestingly, PTR-21 extract treatment can prolong G1 phase from 26 to $40 \%$ (fig. 6). Cell cycle is one of important aspects that has been widely analysed in relation to many therapeutic strategies. G1 phase is the synthesis and accumulation of active proteins required for DNA replication occurring in $\mathrm{S}$ phase. Subsequently, cell cycle will enter S phase, G2 and mitotic, respectively. In a normal condition of fission yeast, the G1 and S phases are relatively short, each occupying $10 \%$ of the cell cycle while the longest phase is G2 and mitotic phase occupies $70 \%$ of the cell cycle $^{[32]}$. Based on these results, PTR-21 extract likely extends G1 phase of yeast cell cycle then slows down aging processes. Simply, yeast cell constantly stayed on a steady state condition, not directly entering $\mathrm{S}$ phase. Some drugs such as ketoconazole and gemfibrozil were reported to increase G1 phase of $S$. pombe cell cycle and give a beneficial effect of counteracting aging ${ }^{[33]}$.

TABLE 4: PHYTOCHEMICAL ANALYSIS OF PTR-21 EXTRACT

\begin{tabular}{lcccccc}
\hline \multirow{2}{*}{ Extract } & \multicolumn{5}{c}{ Phytochemicals content } \\
\cline { 2 - 6 } & Alkaloid & Flavonoid & Saponin & Steroid & Terpenoid \\
\hline PTR-21 & - & + & - & + & - & Tannin \\
\hline
\end{tabular}

'+' indicates positive reaction; '-' indicates negative reaction
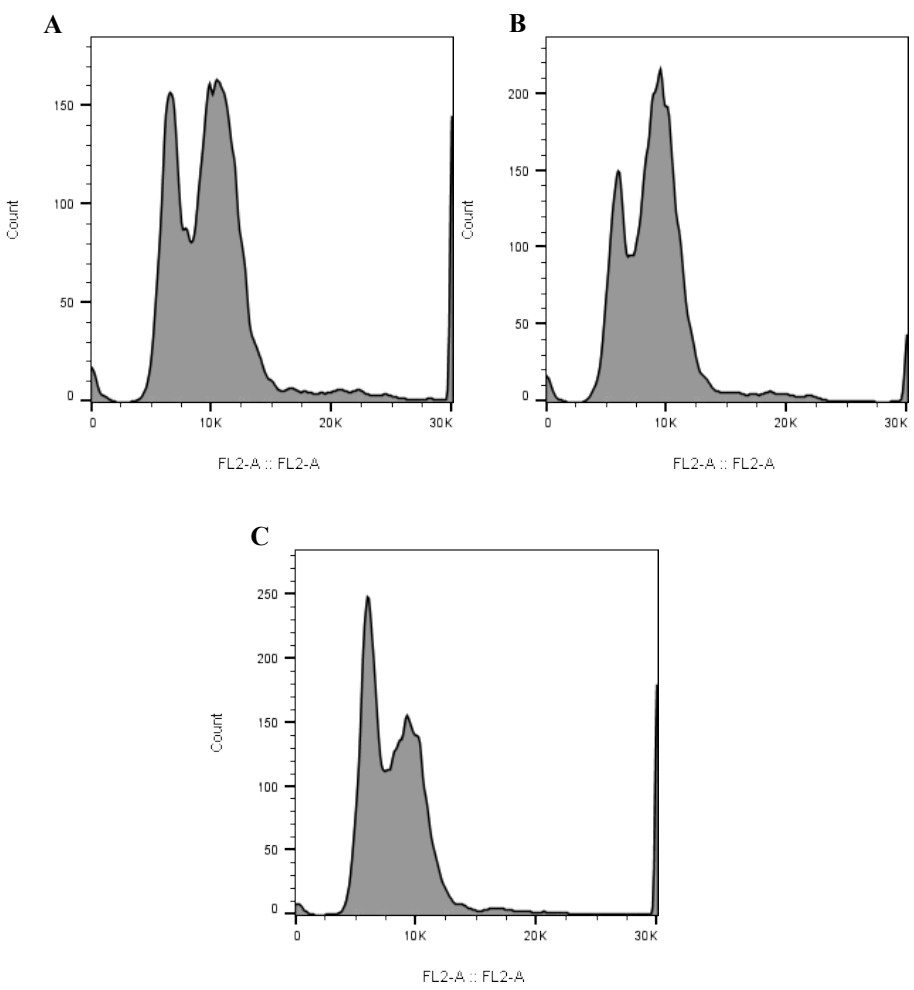

Fig. 6: Effect of PTR-21 extract treatment $(500 \mu \mathrm{g} / \mathrm{ml})$ on the cell cycle distribution of $S$. pombe

A. Cell cycle distribution of wild type $S$. pombe; G1: $26.7 \pm 0.1 \%$, S: $14.0 \pm 0.4 \%$, G2+M: $59.3 \pm 0.5 \%$. B. Cell cycle distribution of $S$. pombe supplemented with DMSO; G1: $27.6 \pm 2.2 \%$, S: 18.4 $\pm 0.8 \%$, G2+M: 54.0 $\pm 2.5 \%$. C. Cell cycle distribution of $S$. pombe after treat with PTR-21 extract; G1: $40.4 \pm 2.8 \%$, S: $16.0 \pm 0.4 \%, G 2+M: 43.7 \pm 3.2 \%$. The percent indicates the total amount of each cell cycle phases. All data are means and representative from three independent experiments 
Based on this study, it could be proposed that PTR21 extract has pro-oxidant mechanism that enhances cellular systems of $S$. pombe to either promote oxidative stress tolerance phenotype or longevity. As prooxidant, PTR-21 exhibits a certain role in promoting mitochondrial activity that is correlated to adaptive ROS-signalling mechanism, which is important for cell survival against oxidative stress and longevity. In addition, PTR-21 causes G1 extension in S. pombe cell cycle that may prolong yeast life span. However, further analysis to deeply investigate especially on some genes correlated with antioxidant defences, mitochondrial function and cell cycle regulation are needed to support this hypothesis.

Furthermore, PTR-21 isolate was identified through morphological and physiological observations. PTR-21 belongs to those Bacilli. Macroscopically, the diameter of bacterial colony after $2 \mathrm{~d}$ growth on Luria agar solid medium was approximately $1.1 \mathrm{~mm}$ at room temperature of $28-29^{\circ}$. The colony colour of the bacteria was yellow, circular on shape, raised on elevation, entire on margin, smooth on surface and moist on texture. Based on these results and biochemical test (Table 3), PTR-21 isolate was closely related to genera Pseudomonas sp. These genera of bacteria have been known to produce various bioactive compounds such as pyrroles, pseudopeptide pyrolidinedione, phloroglucinol, phenazine or benzaldehyde functionally as antibacterial, antitumor or antiproliferative $\mathrm{e}^{[34]}$. Although these genera can produce some bioactive compounds, the effect of the extracts as antiglycation correlating with antiaging effect on $S$. pombe as a model organism has not been reported.

Further, the present work has analysed the phytochemical content of PTR-21extract. The results showed that this extract contained a group of flavonoid, steroid and tannin (Table 4). Phenolic compounds including flavonoids are known to have a dominant antiaging capability in the organisms of either $S$. pombe or Saccharomyces cerevisiae. Phenolic compounds such as phloridzins from Pyrus communis plants have an effect on $S$. cerevisiae by triggering antioxidative genes such as $\operatorname{sod} 1$ and $\operatorname{sod} 2^{[35]}$. Flavonoid groups such as catechins, epicatechins, luteolin and routine were also reported to have such an activity as inhibitors of AGEs formation by trapping carbonyl reactive groups (methylglioxal). At the same time, tannin compounds such elagitanin and elagat acid are known to have hypoglycemic activity. Thus, it can minimize protein glycation $^{[36]}$. Based on the results, it can be expected that PTR-21 extract has the best antiglycation and antiaging activity, causing it to contain flavonoid (phenolic group) and tannin content. However, further analysis to fractionated and elucidated of that active compound is needed to support this hypothesis.

\section{Acknowledgment:}

This research was partly supported by Master program of Education Leading to Doctoral Degree for Excellent Graduated Program 2017/2018, and partly supported by Competance-based Research (Basics Research). We are also expressed thanks a lot to Prof Hiroshi Takagi, $\mathrm{PhD}$ for kindly provided facilities required to carry out some parts of this research through PKPI-sandwich scholarship collaboration program (December 2017 May 2018), between Department of Biology, Bogor Agricultural University and Laboratory of Applied Stress and Microbiology, NAIST, Japan. All of research grant as mentioned above comes from the Ministry of Research, Technology and Higher Education of the Republic of Indonesia to ATW. Therefore, we thank for this funding to conduct this research.

\section{Conflict of interest:}

The authors declared that they have no conflict of interest.

\section{REFERENCES}

1. Taylor MW, Radax R, Steger D, Wagner M. Sponge associated microorganisms: evolution, ecology and biotechnological potential. Microbiol Mol Biol Rev 2007;71(2):295-347.

2. Radjasa OK, Martens T, Grossart H, BrinkhoffT, Sabdono A, Simmon M. Antagonistic activity of a marine bacterium Pseudoalteromonas luteoviolacea TAB4.2 associated with coral Acropora sp. J Biol Sci 2007;7(2):239-46.

3. Utami AWA, Wahyudi AT, Batubara I. Toxicity, anticancer and antioxidant of extracts from marine bacteria associated with sponge Jaspis sp. Int J Pharm Bio Sci 2014;5(4):917-23.

4. Karwati A, Nomura J, Ramli N, Wahyudi AT. Cytotoxicity of crude extract from sponge-associated bacteria against MOLT4 leukemic cell lines through apoptosis. Int J Pharm Pharm Sci 2015;7(12):246-9.

5. Priyanto JA, Astuti RI, Nomura J, Wahyudi AT. Bioactive compounds from sponge associated bacteria: anticancer activity and NRPS-PKS gene expression in different carbon sources. Am J Biochem Biotechnol 2017;13(4):148-56.

6. Kregel $\mathrm{KC}$, Zhang HJ. An integrated view of oxidative stress in aging: basic mechanisms, functional effects, and pathological consideration. Am J Physiol Regul Integr Comp Physiol 2006;292(1):18-36.

7. Tillah M, Batubara I, Sari RK. Antimicrobial and antioxidant activities of resins and essential oil from pine (Pinus merkusii, Pinuso ocarpa, Pinus insularis) and Agathis (Agathis loranthifolia). J Biol Biol Educ 2017;9(1):134-9. 
8. Wahyuni, Malaka MH, Yanti NA, Hartati R, Sukrasno, Sahidin I. Radical scavenging and antibacterial activity of phenolic compounds from Anacardium occidantale L. stem barks from South East Sulawesi-Indonesia. Indian J Pharm Sci 2018; 80(1):143-9.

9. Hori M, Yagi M, Nomoto K, Ichijo R, Shimode A, Kitano $\mathrm{T}$, et al. Experimental models for advanced glycation end product formation using albumin, collagen, elastin, keratin and proteoglycan. J Anti Aging Med 2012;9(6):125-34.

10. Mitchison, JM. My favourite cell: The fission yeast, Schizosaccharomyces pombe. Bioessays 1990;12(4):189-91.

11. Roux AE, Chartrand P, Ferbeyre G, Rokeach LA. Fission yeast and other yeasts as emergent models to unravel cellular aging in eukaryotes. J Gerontol A Biol Sci Med Sci 2010;65(1):1-8.

12. Stephan J, Franke J, Ehrenhofer-Murray AE. Chemical genetic screen in fission yeast reveals roles for vacuolar acidification, mitochondrial fission, and cellular GMP levels in lifespan extension. Aging Cell 2013;12(4):574-83.

13. Tokasaya P. Spons-associated bacteria producing antimicrobial compounds and their genetic diversity analysis [dissertation]. Bogor: Graduated school. Bogor Agricultural University; 2010.

14. Surwenda NA. Screening of Bacteria Producing Antimicrobial Compounds Isolated from Marine Sponges [dissertation]. Bogor: Under graduated school. Bogor Agricultural University; 2014.

15. Ramkissoon JS, Mahomoodally MF, Ahmed N, Subratty AH. Antioxidant and antiglycation activities correlates with phenolic composition of tropical medical herbs. Asian Pac J Trop Med 2013;6(7):561-9.

16. Batubara I, Mitsunaga T, Ohasi H. Screening antiacne potency of Indonesian medicinal plants: antibacterial, lipase inhibition, and antioxidant activities. J Wood Sci 2009;55(3):230-5.

17. Zahra U, Kartika Y, Batubara I, Darusman LK, Maddu A. Screening the potency of Zingiberaceae leaves as antioxidant and antiaging agent. Nus Biosci 2016;8(2):221-5.

18. Roux AE, Quissac A, Chartrand P, Ferbeyre G, Rokeach LA. Regulation of chronological aging in Schizosaccharomyces pombe by the protein kinase Pka1 and Sck2. Aging cell 2006;5(4):345-57.

19. Astuti RA, Watanabe D, Takagi H. Nitric oxide signalling and its role in oxidative stress response in Schizosaccharomyces pombe. Nitric oxide 2016;52:29-40.

20. Boye E, Anda S, Rothe C, Stokke T, Grallert B. Analyzing Schizosaccharomyces pombe DNA content by flow cytometry. Cold Spring Harb Protoc 2016;520-4.

21. Buchanan RE, Gibbons NE. Bergey's manual of Determinative Bacteriology. 8th ed. Baltimore, USA: William and Wilkins Inc.; 1974.

22. Gochukwu SC, Uche AI, Ifeanyi O. Preliminary phytochemical screening of different solvent extracts of stem bark and roots of Dennetia tripetala G. Baker. Asian J Plant Sci Res 2013;3(3):10-13.

23. Policegoudra RS, Saikia S, Das J, Chattopadhyay P, Singh L, Veer V. Phenolic content, antioxidant activity, antibacterial activity and phytodhemical composition of Garcinia lancifolia. Indian J Pharma Sci 2012;74(3):268-71.

24. Arunachalam K, Appadorai RAJ. Antioxidant potential and biochemical evaluation of metabolites from the marine bacteria Virgibacillus sp. associated with the sponge Callyspongia diffusa. Free Radic Antiox 2013;3(1):47-51.

25. Batubara I, Zahra U, Darusman KD, Maddu A. Essential oil of Zingiberaceae leaves as antioxidants and antiglycation. J Essent oil 2016;1(1):1-9.

26. Falcon AA, Aris JP. Plasmid accumulation reduces life span in Saccharomyces cerevisae. J Biol Chem 2003;278(43):4160717.

27. Zuin A, Carmona M, Morales-Ivorra I, Gabrielli N, Vivancos AP, Ayte J, et al. Lifespan extension by calorie restriction relies on the Sty1 MAP kinase stress pathway. EMBO J 2010;29(5):981-91.

28. Shadel GS. Live longer on MARS: a yeast paradigm of mitochondrial adaptive ROS signalling in aging. Microb Cell 2014;1(5):140-4.

29. Lin MT, Beal MF. Mithocondrial dysfunction and oxidative stress in neurodegenerative disease. Nature 2006;443(7113):787-95.

30. Calabrese V, Cornelius C, Dinkova-Kostova AT, Lavicoli I, Paola RD, Koverech A, et al. Cellular stress responses, hormetic phytochemicals and vitagenes in aging and longevity. Biochim Biophys Acta 2012;1822(5):753-83.

31. Mutoh N, Kawabata M, Nakagawa CW, Kitajima S. Pro-oxidant action of phloxin B on fission yeast Schizosaccharomyces pombe. Yeast 2005;22(2):91-7.

32. Hagan IM, Grallert A, Simanis V. Analysis of the Schizosaccharomyces pombe cell cycle. Cold Spring Harb Protoc 2016;2019(9):735-46.

33. Hoose SA, Duran C, Malik I, Eslamfam S, Shasserre SC, Downing SS, et al. Systematic analysis of cell cycle effects of common drugs leads to the discovery of a suppressive interaction between gemfibrozil and fluoxetine. PLoS One 2012;7(5):1-9.

34. Debbab A, Aly AH, Lin WH, Proksch P. Bioactive compounds from marine bacteria and fungi. Microb Biotechnol 2010;3(5):544-63.

35. Xiang L, Sun K, Lu J, Weng Y, Taoka A, Sakagami Y, Qi J. Anti-aging effects of phloridzin, an apple polyphenol, on yeast via the $S O D$ and Sir2 genes. Biosci Biotechnol Biochem 2011;75(5):854-8.

36. Hernawan UE, Setyawan AD. Review: ellagitanin, biosyntesis, isolation andits biological activity. Biopharmacy 2003;1(1):25-38. 